\title{
DNA - Binding and Cleavage Studies of Macrocyclic Metal Complexes Containing Heteroatomic Ligands
}

\author{
NEHA MATHUR* and SONLATA BARGOTYA \\ Department of Chemistry, Govt. P.G. College, Dausa, \\ University of Rajasthan-303303, India \\ nehavmathur@yahoo.co.in
}

Received 25 October 2015 / Accepted 20 November 2015

\begin{abstract}
Designing of improved metal complexes, irreversibly modifying the nucleic acids is important from chemical and biological point of view. In this regard copper nucleases are of great significance, since they form an important class of artificial nuclease possessing biologically accessible redox potentials and high cleavage affinity. Therefore, they are potential reagents for cleavage of DNA. For the same, coordination compounds using $\mathrm{Cu}$ (II) soap with nitrogen and sulphur donor ligands in a $\mathrm{M}: \mathrm{L}$ (1:2) molar ratio of the type $\mathrm{Cu}_{2}\left(\mathrm{C}_{15} \mathrm{H}_{31} \mathrm{COO}\right)_{4} \mathrm{~L}_{2}$ and $\mathrm{Cu}_{2}\left(\mathrm{C}_{7} \mathrm{H}_{15} \mathrm{COO}\right)_{4} \mathrm{~L}_{2}$ where $\mathrm{L}$ are 2-amino 6- bromo benzothiazole, are synthesized and fully characterized by elemental and spectral analysis namely ${ }^{1} \mathrm{H}$ NMR, FT-IR, ESR and Mass spectra. The interaction of complexes with Lactobacillus acidophilus DNA is investigated using agarose gel electrophoresis measurements and visualization of cleavage pattern has been done on UV transilluminator. The result suggests that copper(II) complexes bind to DNA via different modes. Gel electrophoresis study reveals the fact that copper complexes involving nitrogen and sulphur donor moieties cleaves super coiled DNA to nicked linear forms.
\end{abstract}

Keywords: DNA binding, DNA cleavage, Copper palmitate, Copper caprylate Substituted benzothiazole.

\section{Introduction}

For a long time DNA is considered solely a carrier of genetic information. Over the past decades there has been a considerable interest in binding properties of DNA with different metal complexes acting as artificial nucleases under various physiological conditions ${ }^{1}$. This may be due to the variety of potential sites provided by this nucleic moiety to varied chemical agents for efficient co-ordination and multiple interactions in biological environment ${ }^{2-3}$. Such a synergy has been a subject of extensive research and investigations as they share an important place for upcoming genomic researches, forensic sciences, and biotechnology in development of new valuable, improved drugs, therapeutic agents and metal-based anticancer agents ${ }^{4-5}$.

In the aforesaid context, binding and cleavage ability of the transition metal complexes depends on many factors like nature of metal ion and the ligands, size, stereo chemical 
properties of the metal complexes ${ }^{6}$. These factors makes the chemical nucleases lead over the biological nucleases. This is because chemical nucleases being smaller in size can reach more sterically hindered regions of complex macromolecules. This great attention can be continued by manipulating the related ligand species through donor atoms ${ }^{7-9}$.

Relating our literature survey to above scenario studies of Dimroth ${ }^{10}$, Eichhorn ${ }^{11}, \operatorname{Lippard}^{12}$, Sigman $^{13}$, Dervan ${ }^{14}$ and Barton ${ }^{15}$ are worth mentioning. The mechanistic chemical studies on reactions of DNA were provided by Stubbe and Kozarich ${ }^{16-17}$. Sigman's studies showed that metal complexes with nitrogen donor ligands act as artificial nucleases in the presence of molecular oxygen and reducing agents. Some studies reveals that the mechanism of DNA scission induced by metallo complexes may also involves reactive oxygen species (ROS) ${ }^{18-19}$.

Therefore, extensive studies are necessary to evaluate and understand the factors that determine the mode of the binding interaction with DNA. Unfortunately among the aforesaid stuff, macrocyclic copper (II) complexes have received much less attention. The exact mode, mechanism and extent of binding and cleavage in this perspective still remain unknown. This nicking of DNA via different modes like oxidative, electrolytic, photolytic and hydrolytic may be considered a result of structural differences in macrocycles understudy. With our concerned metal ligands containing poly functional donors ( $\mathrm{S}, \mathrm{O}$ and $\mathrm{N}$ ), also gained tremendous attention in a wide perspective ${ }^{20-23}$. The bonding may involve hydrogen bonding, Vander Waals force, hydrophobic interaction or coordination between the metal ion in the complex and base donor atom in DNA probably the nitrogen which would provide an opportunity to obtain structural insight into the binding event.

Therefore, in the current research work, we have synthesized and characterized $\mathrm{Cu}$ (II) complexes which are able to induce effective DNA cleavage activity. The chemical and cleavage reactions that we focus are thematic issues that split the biopolymer by attacking its backbone. The purpose is to understand the selectivity and efficiency of DNA recognized and cleaved by different structural macrocyclic copper complexes and to develop new effective cleaving agents or useful DNA probes.

\section{Experimental}

All the chemicals used were of AR/LR grade. The percentage compositions of $\mathrm{C}, \mathrm{H}, \mathrm{S}, \mathrm{O}$ and $\mathrm{N}$ of complexes were determined by using micro analytical methods on Perkin Elmer elemental analyzer. The formation of complexes was confirmed by using IR, NMR, ESR, Mass techniques and elemental analysis. Melting points were determined on Toshniwal apparatus and were uncorrected. The purity of compounds was checked on Thin Layer Chromatography. IR spectra $(\mathrm{KBr})$ were recorded at IIT Mumbai on FT IR spectrophotometer model $8400 \mathrm{~S}$ Shimadzu as nujol mull using $\mathrm{KBr}$ pellets in the range of 4000-400 $\mathrm{cm}^{-1}$ and ${ }^{1} \mathrm{H}$ was recorded in DMSO-d6 using Bruker DPX-300 spectrophotometers using TMS as internal reference. Mass spectra were also recorded in DMSO d6 at Therachem laboratories, Jaipur. ESR spectra of the complexes were recorded at liquid nitrogen temperature in the X band region at IIT, Mumbai, X-band spectrophotometer equipped with $100 \mathrm{kHz}$ field modulations using Tetracynoethylene (TCNE) as the standard.

\section{Synthesis of ligand}

2-Amino 6- bromo benzothiazole was synthesized using thiocyanogenation method. In this method $(0.1 \mathrm{~mol}) p$-bromo aniline was treated with a mixture of $(0.1 \mathrm{~mol})$ ammonium thiocyanate, $(0.1 \mathrm{~mol})$ cupric chloride and $80 \mathrm{~mL}$ glacial acetic acid in a $250 \mathrm{~mL}$ three necked round bottom flask, with stirrer, dropping funnel and reflux condenser at room 
temperature for one and half hour. The thiocyanogenation of aryl amine takes place in the presence of thiocynogen gas, which was generated in situ by the reaction of cupric chloride and ammonium thiocynate.

After cooling the reaction mixture, $100 \mathrm{~mL}$ concentrated $\mathrm{HCl}$ was added and heat again for half an hour, then cooled it and then saturated solution of sodium carbonate $\left(\mathrm{Na}_{2} \mathrm{CO}_{3}\right)$ was added to neutralize it, till the solid was formed. The solid separated out was filtered and washed with cold water, dried and recrystallised with ethanol (Scheme 1).<smiles>Nc1ccc(Br)cc1</smiles>

Scheme 1. Synthesis of 2 amino 6-bromo benzothiazole

\section{Synthesis of copper surfactants}

Copper palmitate / copper caprylate were prepared by mixing $1 \mathrm{~g}$ of palmitic acid / caprylic acid into $25 \mathrm{~mL}$ ethyl alcohol, the mixture was shaken in hot water bath and then one drop of phenolphthalein was added. A saturated solution of $\mathrm{KOH}$ in another beaker was prepared then it was added into Palmitic acid / Caprylic acid solution drop by drop until the light pink color appears. Now again in another beaker a saturated solution of $\mathrm{CuSO}_{4}$ (about 2-3 $\mathrm{g}$ in 5 $\mathrm{mL} \mathrm{H}_{2} \mathrm{O}$ ) was prepared and mixed it into above solution with stirring till the blue colored soap is formed. Filtered and washed with warm water and $10 \%$ ethyl alcohol then dried and recrystallised with hot benzene (Scheme 2).

$$
\begin{aligned}
& \mathrm{RCOOH} \\
& \text { Fatty acids }
\end{aligned} \underset{\text { Copper Sulphate }}{\mathrm{CuSO}_{4}}+\underset{\text { Ethanol }}{\mathrm{C}_{2} \mathrm{H}_{5} \mathrm{OH}} \longrightarrow \underset{\text { Copper Surfactants }}{(\mathrm{RCOO})_{2} \mathrm{Cu}}
$$

Here, $\mathrm{R}=\mathrm{C}_{15} \mathrm{H}_{31}$ for Palmitic Acid and $\mathrm{C}_{7} \mathrm{H}_{15}$ for Caprylic acid

Scheme 2. Synthesis of copper surfactants

\section{Preparation of copper complexes}

The complexes of copper palmitate (CP(BTA))/ copper caprylate (CC(BTA)) and substituted benzothiazole were prepared by adding ( $0.001 \mathrm{~mol})$ copper palmitate/ copper caprylate with $(0.002 \mathrm{~mol})$ substituted benzothiazoles in $25-30 \mathrm{~mL}$ ethyl alcohol and the mixtures were refluxed for about two hours with constant stirring. After cooling the precipitate were filtered, dried and recrystallized with hot benzene (Scheme 3).

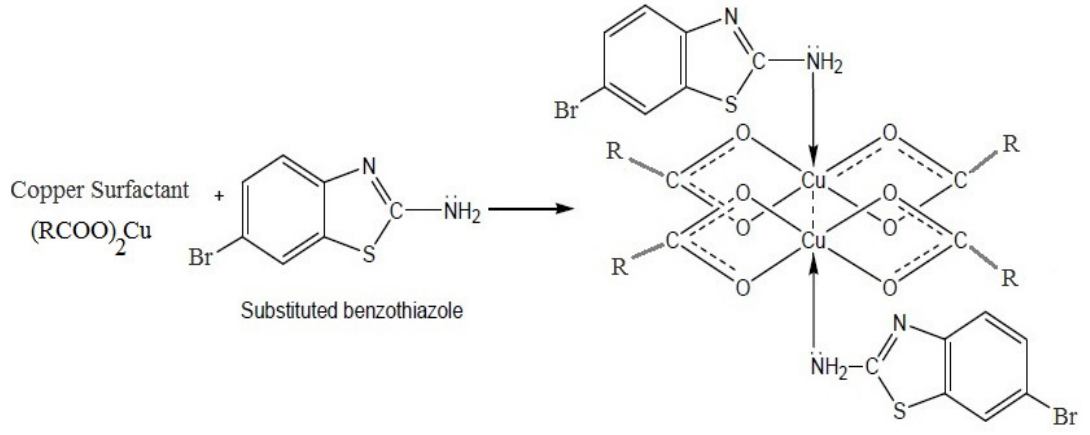

Scheme 3. Complexation of copper surfactant with substituted benzothiazole 
[CP(BTA)]: Yield: $2.87 \mathrm{~g}]$ Analysis: Calculated for $\mathrm{C}_{78} \mathrm{H}_{134} \mathrm{O}_{8} \mathrm{~N}_{4} \mathrm{~S}_{2} \mathrm{Br}_{2} \mathrm{Cu}_{2}:$ C, 58.33; H, 8.36; O, 7.97; N, 3.49; S, 3.98; Br, 9.96; Cu, 7.91; Found C, 58.30; H, 8.30; O, 7.95; N, 3.42; S, 3.92; Br, 9.94; Cu,7.88. MS in DMSO d6: $\mathrm{m} / \mathrm{z}(\%): 722.5$ (70), $678.5(90), 668.3$ (70), 634.5 (100), 590.5 (87). IR / cm ${ }^{-1}: 3450.00 \mathrm{~s}, 2950.00 \mathrm{~s}, 2851 \mathrm{~s}, 2149.97 \mathrm{~s}, 1600$ m, 1500 m, 1334.50 m, 1180 w, 810 w, 580 w, 450 w. 1H NMR (400 Mz, DMSO-d6, $\delta) 0.84$ $\left(\mathrm{CH}_{3}-, 12 \mathrm{H}\right), 1.22\left(-\mathrm{CH}_{2}-, 112 \mathrm{H}\right), 3.80\left(-\mathrm{NH}_{2}, 4 \mathrm{H}\right), 7.82(\mathrm{Ar}-\mathrm{H}, 6 \mathrm{H})$.

[CC(BTA)]: Yield: 1.79g ] Analysis: Calculated for $\mathrm{C}_{46} \mathrm{H}_{70} \mathrm{O}_{8} \mathrm{~N}_{4} \mathrm{~S}_{2} \mathrm{Br}_{2} \mathrm{Cu}_{2}$ : C, 47.71, H, 6.06; O, 11.06; N, 4.85; S, 5.53; Br, 13.82; Cu, 10.97; Found C, 47.66; H, 6.03; O, 11.05; N, 4.81; S, 5.52; Br, 13.79; Cu, 10.90. MS in DMSO d6: $\mathrm{m} / \mathrm{z}(\%): 683.3$ (60), 639.3 (75), 595.3 (95), 551.2 (100), $507.3(90)$. IR / cm ${ }^{-1}: 3445.75 \mathrm{~s}, 2954.31 \mathrm{~m}, 2853.62 \mathrm{~m}, 2154.99 \mathrm{~s}, 1588.78 \mathrm{~s}$, $1527.18 \mathrm{w}, 1480.85 \mathrm{w}, 1306.00 \mathrm{w}, 1118.35 \mathrm{w}, 836.94 \mathrm{w}, 512.61 \mathrm{w}, 481.09 \mathrm{w}$; 1H NMR (400 Mz, DMSO- $d 6, \delta) 0.96\left(\mathrm{CH}_{3}-12 \mathrm{H}\right), 1.21\left(-\mathrm{CH}_{2}-48 \mathrm{H}\right), 3.99\left(-\mathrm{NH}_{2}, 4 \mathrm{H}\right), 7.82(\mathrm{Ar}-\mathrm{H}, 6 \mathrm{H})$.

\section{DNA cleavage analysis of synthesised compounds on bacterial DNA}

The study was conducted in three main steps:

\section{Isolation of genomic DNA}

$24 \mathrm{~h}$ Old culture (primary culture) of Lactobacillus acidophilus was taken growing on nutrient broth (Peptone- $5 \mathrm{~g}$, Beef extract $-3 \mathrm{~g}$, Sodium chloride- $5 \mathrm{~g}$, distilled water- $1000 \mathrm{~mL}, \mathrm{pH}-7.0$ autoclaved at $1210{ }^{\circ} \mathrm{C}, 15 \mathrm{psi}$ pressure and $15 \mathrm{~min}$ ). The media was inoculated with the ATCC 25922 culture of Lactobacillus acidophilus. The primary culture was transferred to the fresh nutrient broth ( $25 \mathrm{~mL}$ primary culture and $25 \mathrm{~mL}$ fresh medium) to obtain secondary culture.

Isolated bacterial DNA sample was supplemented with of $5 \mathrm{mg} / \mathrm{mL}$ of synthesised complexes. Three flasks were taken (secondary culture) loaded with two different concentrations of sample A and B respectively. Flask no. 1 served as untreated control, Flask no. 2 with $5 \mathrm{mg} / \mathrm{mL}$ of [CP(BTA)] as sample A, Flask no. 3 with $5 \mathrm{mg} / \mathrm{mL}$ of $[\mathrm{CC}(\mathrm{BTA})]$ as sample B.

Agarose Gel Electrophoresis and visualization of cleavage pattern on UV transilluminator. Cultures were incubated for $48 \mathrm{~h}$ for DNA cleavage and after $24 \mathrm{~h}$ of incubation the DNA was isolated and the bands were visualized on UV transilluminator.

\section{Protocol for isolation of genomic DNA}

$1000 \mu \mathrm{L}$ bacterial culture was taken from secondary cultura and centrifuged at $6000 \mathrm{rpm}$ for $10 \mathrm{~min}$ and the pellets were collected and treated with $250 \mu \mathrm{L}$ cell lysis buffer. Again centrifuged it at $10000 \mathrm{rpm}$ for $10 \mathrm{~min}$. Now, supernatant was collected and treat with 250 $\mu \mathrm{L}$ phenol: chloroform: isoamyl alcohol (25:24:1). Centrifuged for $10000 \mathrm{rpm}$ for $10 \mathrm{~min}$, the upper aqueous layer was collected. Double amount of chilled ethanol $+50 \mu \mathrm{L}$ of sodium acetate was added and inverted once. Incubated at $-20 \circ \mathrm{C}$ for $1 \mathrm{~h}$. Centrifuged and collected pellet were stored it in $100 \mu \mathrm{L}$ T.E buffer.

\section{Protocol for agarose gel electrophoresis}

$0.5 \mathrm{X}$ TBE by diluting appropriate amount of $10 \mathrm{X}$ TBE buffer were prepared. $0.6 \mathrm{~g}$ of agarose was weighed and added to $50 \mathrm{~mL}$ of IX TAE. This gives $1.2 \%$ agarose gel. Boiled till agarose dissolves completely and a clear solution results. Meanwhile the combs of electrophoresis set were placed such that it is approximately $2 \mathrm{~cm}$ away from the cathode. The agarose solution was poured in the central part of tank when the temperature reaches approximately $60{ }^{\circ} \mathrm{C}$. Air bubbles are not allowed to generate. The thickness of the gel is around 0.5 to $0.9 \mathrm{~cm}$. 
The gel was kept undisturbed at room imple ura for the agarose to solidify. 0.5X TBE buffer was poured into the gel tank till the buffer level stands at 0.5 to $0.8 \mathrm{~cm}$ above the gel surface. The combs were gently lift to ensuring that impl remain intact. The power cord was connected to the electrophoresis power supply according to the convention red: anode, black: cathode. The samples were loaded in the impl in the desired order. The imple was set to $50 \mathrm{~V}$ and switched on the power supply. The gel was allowed to run for more

im half the length of gel. The power supply was switched off and visualized Gel under UV-trans-illuminator for interpretation of the result.

\section{DNA cleavage analysis}

After the cleavage of the DNA with the chemical treatment at $5 \mathrm{mg} / \mathrm{mL}$ concentration the banding pattern was analyzed by agarose gel electrophoresis using $1.2 \%$ agrose gel. The cleavage pattern was detected after $48 \mathrm{~h}$ and $96 \mathrm{~h}$ of incubation; the bands were visualized on UV-transilluminator. DNA ladder was used 100-1000bp (100 bp step up ladder, Merck).

\section{Results and Discussion}

In the aforesaid experiment following lanes were obtained on UV trans-illuminator

iii) Lane 1- uncleaved control Lactobacillus acidophilus Genomic DNA

ii) Lane 2- cleaved DNA with imple A $5 \mathrm{mg} / \mathrm{mL}$

iii) Lane 3- cleaved DNA with imple B $5 \mathrm{mg} / \mathrm{mL}$

From a detail historical background and valuable articles on metal depended cleavage of nucleic acids, one can probably predict the pathway of this biological event ${ }^{23}$. Interactions of transition-metal complexes with nucleic acids have been studied two categories:

(i) Those involving a redox reaction of the metal complex with oxidation of the nucleic acid.

(ii) Those involving coordination of the metal centre to the sugar-phosphate backbone so as to mediate the cleavage of the nucleic polymers.

The ability of the synthesized complexes to affect DNA cleavage was investigated by gel electrophoresis using Lactobacillus acidophilus DNA. The complexes were found to exhibit significant nuclease activity. The cleavage efficiency of the complexes was compared with that of the control (untreated DNA).

In the present study, the DNA gel electrophoresis experiment was conducted at $35^{\circ} \mathrm{C}$ using our synthesized complexes as oxidants. Control experiment using DNA alone does not show any significant cleavage of DNA even on longer exposure time. But on treatment of DNA with synthesised complexes, redox property of the metal complexes mediates oxidation of nucleic acids and the metal complexes were able to degrade DNA effectively.

On comparing the DNA cleavage by both complexes we see that more effective cleavage is obtain by $\mathrm{CC}(\mathrm{BTA})$ than $\mathrm{CP}(\mathrm{BTA})$. This can easily be visualised by cleavage patterns of DNA (Figure 1). Here, we see that Lane-I represents the untreated DNA. This DNA is not degraded throughout the lane. Lane-II consists of DNA treated with CP(BTA). Visualizations predict a bit of smearing in DNA. Lane-II shows DNA cleavage pattern treated by CC(BTA). We see that here the cleavage is much more effective than that of Lane-II.

The gel electrophoresis images clearly reveal that the intensity of all the treated DNA samples has vanishes, possibly because of the disruption of the DNA. It shows that the control DNA alone does not show any apparent cleavage whereas the synthesised complexes show cleavage. 


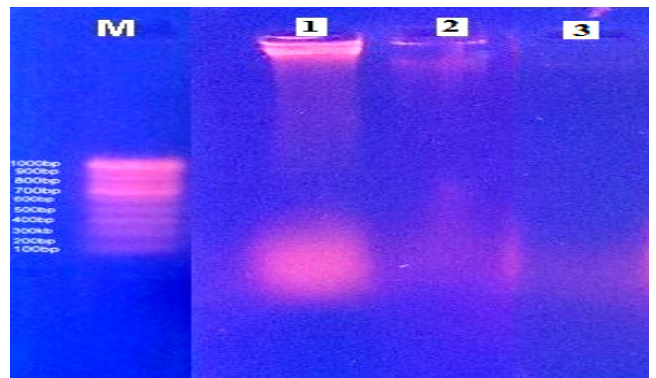

Figure 1. Image depicting the cleavage pattern of Lactobacillus acidophilus DNA

A general oxidative mechanism has been suggested for DNA binding and cleavage by abstraction of a hydrogen atom from sugar units and predicts the release of specific residues arising from transformed sugars, depending on the position from which the hydrogen atom is removed. The possible proposed mechanism can take place at two levels:

1. Carbohydrate level 2. Nucleic base level

At carbohydrate level abstraction of one of the hydrogen of deoxyribose can initiate the cleavage process. At nucleic base level it can occurs probably at guanine ${ }^{24-25}$.

Base metal ion in the complexes may also react and attacks at the C4' position of the sugar moiety and finally cleaves the DNA (Figure 2). Due to the cleavage, intensity of DNA band decreases led to extensive degradations, resulting in the disappearance of bands on agarose gel, which can be observed in Lane-II \& III of Figure 1.

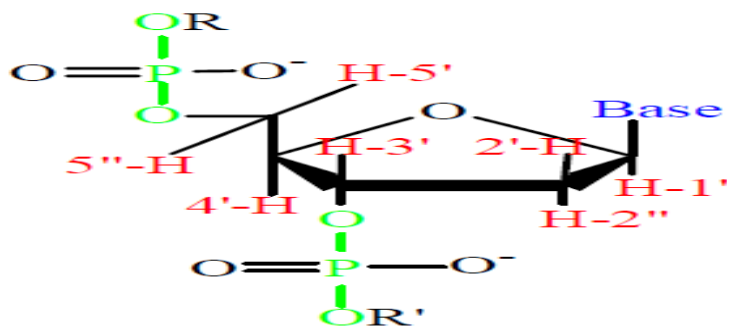

Figure 2. Backbone of Lactobacillus acidophilus DNA specifying the site of incision

However, the nature of reactive intermediates involved in the DNA cleavage by the complexes is not clear. The results indicate that the metal ions play an important role in the cleavage of isolated DNA. As the compound was observed to cleave the DNA, it can be concluded that the compound inhibits the growth of the pathogenic organism by transforming the genome.

\section{Conclusion}

Complexes were synthesized using common fatty acids, nitrogen and sulphur donor ligands. Both the synthesised complexes effectively cleave the Lactobacillus acidophilus DNA. Not only this, synthesised transition metal complexes possess a number of biological applications. Among transition metal complexes the activity of copper complexes is significantly high ${ }^{26-29}$. These compounds show bright path towards pharmaceutical as well as chemical sciences, showing a significant promise as therapeutics, diagnostic probes and foot printing agents ${ }^{30-32}$. But still there is need to explore some of more biological properties for their wide applicability and significant usage in multiple fields because it is an untapped area 
with potentially tremendous value. Such a new innovations and inventions may be useful to foot printing studies, studying specific DNA binding agents, as diagnostic researches in biotechnology, medicinal applications, and potential applications for genomic research. The ability of metal complexes to cleave nucleic acids efficiently, in a non-degrading manner and with high levels of selectivity for a site, sequence will offer many applications for the manipulation of genes, the design of structural probes and the development of novel therapeutics.

\section{Acknowledgment}

The authors express their sincere thanks to the Principal and Head of the Department of Chemistry, Pt. N.K.S. Govt. P.G. College, Dausa for providing laboratory facilities. Special thanks to Therachem laboratories, Jaipur and IIT Mumbai for providing spectral data of ligands and complexes. Thanks also to Dr. B. Lal clinic of Biotechnology, Jaipur for biocidal studies. One of the authors Ms. Sonlata Bargotya is also grateful to UGC, New Delhi for sanctioning Junior Research Fellowship.

\section{References}

1. Flores A F C, Flores D C, Oliveira G, Pizzuti L, Silva R M S, Martins M A P and Bonacorso H G, J Braz Chem Soc., 2008, 19, 184-193.

2. Yuan C X, Wei Y B and Yang P, Chin J Chem., 2006, 24(8), 1006-1012; DOI:10.1002/cjoc.200690188

3. Pyle A M, Long E C and Barton J K, J Am Chem Soc., 1989, 111(2), 4520-4522; DOI:10.1021/ja00194a070

4. Arounaguiri S, Easwaramoorthy D, AshokKumar A, Datta Gupta A and Maiya B G, Proc Indian Acad Sci Chem Sci., 2000, 112, 1-17.

5. Liu H K and Sadler P J, Acc Chem Res., 2011, 44(5), 349-359; DOI:10.1021/ar100140e

6. Erkkila K E, Odom D T and Barton J K, Chem Rev., 1999, 99(9), 2777-2796; DOI:10.1021/cr9804341

7. Deepalatha S, Sambasiva P and Venkatesan R, Spectrochimica Acta Part A, 2005, 64(1), 178-187; DOI:10.1016/j.saa.2005.07.014

8. Dhara K, Ratha J, Manassero M, Wang X, Gao S and Banerjee P, J Inorg Biochem., 2007, 101(1), 95-103; DOI:10.1016/j.jinorgbio.2006.08.010

9. Alvarez G M, Alzuet G, Borras J, Maccias B and Castineiras A, Inorg Chem., 2003, 42(9), 2992-2998; DOI:10.1021/ic020611n

10. Dimroth K, Witzel H, Huelsen W and Mirbach W, Ann Chem., 1959, 620, 94-108.

11. Butzow J J and Eichhorn G L, Biochemistry, 1971, 10, 2019-2027.

12. Elmroth S K and Lippard S J, J Am Chem Soc., 1994, 116(8), 3633-3634; DOI:10.1021/ja00087a073

13. Sigman D S, Mazumder A and Perrin D M, Chem Rev., 1993, 93(6), 2295-2316; DOI:10.1021/cr00022a011

14. Dervan P B, Nature, 1992, 359, 87-88; DOI:10.1038/359087a0

15. Barton J K, Science, 1986, 233, 727-734.

16. Stubbe J, Kozarich J W, Wu W and Vanderwall D E, Acc Chem Res., 1996, 29(7), 322330; DOI:10.1021/ar9501333

17. Stubbe J and Kozarich J W, Chem Rev., 1987, 87(5), 1107-1136; DOI:10.1021/cr00081a011

18. Sigman D S and Chen C B, Annu Rev Biochem., 1990, 59, 207-236.

19. Tullius T D and Greenbaum J A, Current Opinion Chem Bio., 2009, 9(4), 127-134; DOI:10.1016/j.cbpa.2005.02.009 
20. Pillai V V and Sreekanth B, Int J Pharm Bio Sci., 2013, 4(3), 739.

21. Kavitha P and Reddy K L, Bioinorg Chem Appl., 2014, 1-13; DOI:10.1155/2014/568741

22. Akila E, Usharani M and Rajavel R, J Chem Pharm Res., 2012, 4(1), 726-731.

23. Chitrapriya N, Park A J, Wei Wang A, Lee A H and Kim S K A, Metallomics, 2012, 4, 417-421; DOI: 10.1039/C2MT20015E

24. Bashkin J K, Chem Rev., 1998, 98(3), 937-938; DOI:10.1021/cr970415b

25. Gowda S, Mathew B B, Sudhamani C N and Bhojya Naik H S, Biomed Biotech., 2014, 2(1), 1-9.

26. Kochetkov N K and Budovskii E I, Org Chem Nucleic Acids, 1972, 381-423.

27. Liu J, Zhang T, Lu T, Qu L, Zhou H, Zhang Q and Ji L, J Inorg Biochem., 2002, 91, 269-276; DOI: 10.1016/S0162-0134(02)00441-5

28. Chakravarty A R, J Chem Sci., 2006, 118(6), 443-453; DOI:10.1007/BF02703941

29. Ren R, Yang P and Han G Y, Chin Chem Lett., 1999, 10(5), 383 - 386.

30. Kandelous H M, Norouzi M, Hosseini Z S, Ghasemi S and Salimi M, Res Pharm Sci., 2012, 7(5), S442.

31. Ronconi L and Sadler P J, Co-ord Chem Rev., 2007, 251(13-14), 1633-1648; DOI:10.1016/j.ccr.2006.11.017

32. Borowska J, Sochacka E, Sanna D E and Lodyga-Chruscinska E, J Biol Inorg Chem., 2015, 20(6), 989-1004; DOI:10.1007/s00775-015-1282-2 